\title{
Project (I)solation - Everyday Life and Media Use During the COVID-19 Pandemic
}

\author{
Ádám GULD \\ University of Pécs \\ Pécs, Hungary \\ e-mail: guldadam@commonline.hu
}

\begin{abstract}
The pandemic has placed our relationship with digital media in a new context. Regardless of age, the isolation had significant impact on our everyday routines, of which media use has become a constant factor in one form or another. We may have never tried to use so many new applications in such a short time before, as for many of us media was the only connection to the outside world. However, after the quarantine, there are several questions that may arise following the extreme situation. Were we captured or rather liberated by the online media? What did we learn about online life and our relationship with the media during the epidemic? How could the digital generation adapt itself to the new circumstances? What challenges and problems did Generation $\mathrm{Z}$ face during the quarantine? How have young people's daily routines, media use patterns, news consumption, learning and/ or working habits changed? How about their general attitudes towards the media and their effects on them? In the study below, I seek answers to these questions based on the results of an international, interdisciplinary research project called TOGETHER initiated by the University of Pécs (Pécs, Hungary) and Hochschule für Kommunikation und Gestaltung (Stuttgart, Germany).
\end{abstract}

Keywords: media use, pandemic, Generation Z, effects, everyday life

\section{Introduction}

The first scientific article on the virus known as COVID-19 appeared in a medical journal in January $2020,{ }^{1}$ and the first description of the symptoms of the disease dates from December 2019. Although the origin of the virus is unknown, and to the best of our knowledge the pathogen was already present in several parts of the world as early as $2019,{ }^{2}$ many consider China as the starting point for the

1 https://www.thelancet.com/journals/lancet/article/PIIS0140-6736(20)30185-9/abstract.

2 https://www.reuters.com/article/us-health-coronavirus-italy-sewage/italy-sewage-studysuggests-covid-19-was-there-in-december-2019-idUSKBN23Q1J9. 
epidemic. $^{3}$ The epidemic that unfolded in early 2020 , as well as the pandemic that was following it, resulted in huge changes around the world in a matter of weeks: hundreds of millions of people were forced into quarantine, entire institutional systems shut down, entire industries were closed down overnight - the world suddenly fell silent. These circumstances had a serious impact on the relationship between the media and consumers as for many the media was the only connection to the outside world, thus playing a central role during the pandemic. During the period under discussion, the use of traditional media functions (such as providing information and entertainment) also intensified, and new functions (working, learning, social contact, and communication) were added to the usual practices, some of which were already available, but they became even more important in the wake of the pandemic.

What was only conceivable at the beginning of 2020 is now clear: the situation has generated significant changes; media supply and consumer demand have interacted in response to the epidemic, which means that not only the media has affected consumer behaviour, but the new consumer needs also affected how media works today. This transformation was surrounded by huge professional and market interest, so as early as March 2020 relevant international research programmes were launched to map changes in media use during the pandemic. A significant part of the research projects in question addressed the extent to which identifiable changes can be related to the social/cultural embeddedness of media audiences and, more importantly for the present study, how these changes adapt to differences along generational boundaries.

One of the most cited summaries on the topic is related to the Global Web Index research carried out between 25 and 30 March 2020, addressing changes in media use during the pandemic. ${ }^{4}$ Through a sample of 4,000 people, the researchers explored how the pattern of media consumption has changed during the pandemic in an international comparison and what variances can be identified between different generations in this context. ${ }^{5}$ Some important, general results of the research revealed that during the quarantine period $80 \%$ of media users consumed more content, and the dominance of television and online content was rather characteristic. The study also confirmed that during the outbreak of the epidemic users consumed far more news than before and $68 \%$ of people were informed about current news on the epidemic with the help

3 http://weekly.chinacdc.cn/en/article/id/e53946e2-c6c4-41e9-9a9b-fea8db1a8f51.

4 https://www.globalwebindex.com/hubfs/1.\% 20Coronavirus\%20Research\%20PDFs/ GWI\% 20coronavirus \% 20findings \% 20April \% 202020\% 20-\% 20Media \% 20Consumption \% 20 (Release\% 204).pdf.

5 I present the main conclusions of the research here because, on the one hand, the results of the Global Web Index have become an important reference point in connection with the phenomenon studied here, and, on the other hand, the qualitative research carried out within the frameworks of the TOGETHER programme may refine its results. 
of the World Wide Web. From a market point of view, it is not incidental that the proportion of new subscriptions increased significantly during the period under review, with Netflix being the biggest winner, which, as will be discussed later, was able to succeed during the quarantine in age-groups with typically low subscription ratio. The research by the Global Web Index has also examined consumer attitudes, and the results show that media content generated serious tensions over the period in question. The study also found that it was not the time spent on media use that caused the problem but rather the consumption of certain content that was not considered prudently, leading to frustration and anxiety. The main reason of this phenomenon was that during the time spent on increased media consumption users did not consume useful information or light, entertaining content but browsed disturbing social media shares, some of which fell into the category of rumour and fake news.

The Global Web Index research also pays special attention to the question of what changes have taken place in the media use of different generations. ${ }^{6}$ The research worked with four age-groups: mature generations, i.e. boomers (aged 55-75 years) and the Generation X (aged 40-54 years) and younger generations, i.e. the Generation Y (aged 25-39 years) and Generation Z (9-23 years old). Based on the results, the media use of the boomer generation has changed the least during the quarantine; in their case, radio still plays a major role, but they also consumed significant amounts of content in the form of online videos and online press. Among boomers, television remains the leading mass medium, and during the quarantine they spent even more time watching traditional, linear television content - in this age-group, this is the most important change that the research could detect compared to their normal habits prior to the pandemic. The international research has revealed that members of Generation X spent more time watching television in the time interval studied than any other age-group. At the same time, in addition to linear television, they also watched online television broadcasts, so the increased time spent on television was mainly shared by these two platforms. Within this age-group, the consumption of online videos and online press materials can also be considered significant, but listening to the radio was not uncommon either. Of the age-groups in the sample, the media use of Generation Y appears to be the most colourful since they were consuming more content on almost all platforms during quarantine than before. Of these, the importance of online videos and online television also stand out, but, contrary to popular belief, members of this age-group still spent a significant amount of time watching traditional, linear television content as well. Members of this generation also consumed more content on the interfaces of online press and online music streaming services. In the case of Generation $\mathrm{Z}$ youth, the preference for online

6 For the generational segmentation and characteristics of the digital generation, see: HoweStrauss, 1991; Mackay, 1997; Prensky, 2001. 
platforms is overwhelming, and in particular the popularity of online video content and online television programmes is outstanding. In addition, members of this age-group enjoyed browsing Internet news sites, and the use of online music streams also increased, while the practice of listening to the radio and reading print media was almost completely relegated to the background.

The research cited here provides interesting and valuable information for all age-groups; however, in this case as well, marketers paid special attention to what Generation $\mathrm{Z}$ did in the quarantine. The increased interest is due to the consideration that Generation $\mathrm{Z}$ young people, also known as digital natives, are a "trend-setter generation", which means that future trends can be predicted by studying their consumption patterns such as their media use (Törőcsik, 2015). This finding is based on the observation that the media use practices and habits observed in this age-group (use of devices and applications, popularity of social networking sites, etc.) have a wide impact on consumer trends, and typically with a one- to two-year lag these appear among the practices of older users as well. In the light of this finding, it is even more important to understand the changes that followed the pandemic that began in 2020, in the media use of Generation Z youth and to see whether these may have a long-term impact in the future.

The research projects mentioned so far were, without exception, quantitative, large-sample studies that reveal important general, large correlations. At the same time, we have far fewer qualitative results on the subject. The study of PTE (University of Pécs) and HFK $+\mathrm{G}$ (Hochschule für Kommunikation und Gestaltung) in Stuttgart described below sought to fill this gap; the interdisciplinary, qualitative research project implemented with international cooperation can be considered as a deep social and cultural drilling on the topic. A detailed presentation of the project and research is provided below.

\section{TOGETHER - Communication and Design for Intercultural Understanding: The Institutional Background of the Research, Methodological Foundations, Methods, and Informants}

TOGETHER is a research project proposed by the University of Applied Sciences for Communication and Design (in German: Hochschule für Kommunikation und Gestaltung, HfK $+\mathrm{G}$ ) and funded for 3 years by the Ministry of Science Research and Art in Baden-Württemberg. The project is based on an innovative teaching concept for intercultural understanding, especially with regard to the Danube region. The interdisciplinary approach of HfK+G's two study programmes, Communication Design (B.A.) and Advertisement and Market Communication 
(B.A.), lays the foundation for the 4 workshops carried out within the scope of the project, continuing these workshops throughout the semester, thus embedding them in the curricula of the study programmes. Students from all three institutions, the HfK+G in Germany, the Josip Juraj Strossmayer University of Osijek (Croatia), and the University of Pécs (Hungary), were given the chance to participate in the 4 workshops, two of which took place in Germany (Stuttgart and Ulm) and one each in Hungary and in Croatia. Within 10 days of each workshop, students jointly do research in an international environment, with a special focus on local cultural, social, and urban needs (e.g. democratic values, social participation and responsibility, diversity, discrimination, intolerance, integration, etc.). In order to find solution approaches, active participation and dialogue-promoting methods, such as Design Thinking, Citizen Design, science platforms, the World Café method as well as Open Space formats, are used with the contribution of experts in the field and with the involvement of the local society. Analogue, digital, and interactive focused design and communication concepts as well as interdisciplinary solution approaches are deduced by the students in the frame of the workshops. After each workshop, they exhibit their results, thus making them available for the public dialogue. During the semester, the students continue working on the topics at their home universities. In each case, the research projects were implemented in five phases as follows.

Phase 1: Contextualization. This phase starts with research, field work with local target groups, observing, questioning, recognizing, and analysing in order to approach the topic and identify socially relevant problems. It is followed by exploration using Design Thinking research techniques such as A Day in a Life, Behavioural Mapping, Shadowing, Five Whys, or Cultural Probes. Then we rely on the impulse and input from experts, locals, stakeholders, and professors, and we use discussion and dialogue-promoting formats such as Citizen Design Science, the World Café method, and Open Space.

Phase 2: Analysing. Based on phase 1, we derive socially relevant questions to be further addressed. After this, we use Design Research and Design Labs with mood boards, videos, photography, sketches, and text material to evaluate and classify the results, while we also apply economic methods such as SWOT analysis, Business Model Canvas, Ansoff Matrix, Product Life Cycle analysis, or Brand Steering Wheel.

Phase 3: Brainstorming, strategy formation, and concept. After splitting up into groups, students develop their first ideas, strategies, and concepts while using visualization techniques. In this phase, we apply methods such as narration, cognitive maps, conceptual landscapes, and finally we elaborate design approaches such as Look and Feel. 
Phase 4: Prototyping. Prototyping (e.g. paper prototypes, mock-ups) and testing them with local stakeholders while using methods such as Behavioural Sampling, Experience Prototypes, Empathy Tool, Role Playing, or Scenario Testing.

Phase 5: Presentation and feedback. Presentation of communication strategies and design approaches happens in this phase followed by the feedback including local target groups. The programme ends with the presentation of the final strategy, selection of the best concepts, presentations, and realization in cooperation with industrial, cultural partners or with administration and politics.

The implementation of the workshop in Pécs, planned for the spring of 2020, failed because of the COVID-19 epidemic and the subsequent quarantine and isolation. During this period, the role of the media became a central issue, so the organizers of the programme decided that the behaviour and attitudes of quarantined users would be the focus of the study, with partly preserving the methodological principles described above and partly by adapting them to the new situation. Adapted to the circumstances, the research was carried out using online platforms (e.g. Facebook, Zoom, Skype, and Miro Brainwriting), while the central methodological tool of the quarantine research (using a qualitative approach) was the quarantine diary, an auto ethnographic approach belonging to the group of media ethnography. ${ }^{7}$ Students participating in the programme (25 Hungarian and German Generation Z students between the ages of 18 and 25) recorded their quarantine experiences for one week while supplementing written documents with images, videos, drawings, and design solutions according to the five phases described above. In September, the programme will result in an online website featuring interactive audio-visual material that can provide a comprehensive picture of the quarantine experiences of Generation Z youth, particularly in terms of media use. The present study systematizes and interprets these findings through a detailed discussion of five topics: 1) daily routine and media, 2) general pattern of media consumption, 3) news consumption, 4) online learning and work, and 5) media effects. ${ }^{8}$

7 For more information, see: Hepp et al., 2011; Gunter, 2009: 22-55; Horning, 2009: 95-115; Sheble-Wildemuth, 2009; Stokes, 2008: 143-172.

8 From a methodological and theoretical point of view, the research project on Generation Z, which took place between 2013 and 2016 at the University of Pécs, can be considered the antecedent of this research. For more information, see: Törőcsik, 2015; Guld, 2014; Guld-Maksa, 2013. 


\section{Results}

\section{Daily Routine and Media}

One of the central questions of the research was how the position of media developed in everyday life during the quarantine period. The answer to the question was basically a summary of the activities recorded in the diaries as in these texts the students indicated not only when and what media platform they were using but also how the activity fitted into their daily routine and how it all adapted to the changing environment (Picture 1). Based on the results, it can be stated that media became a central factor in everyday life during quarantine, i.e. in many cases it emerged as an organizing force of the daily routine. Media was present in the lives of users from the moment of awakening until late at night, which would not be surprising at all in the case of Generation $\mathrm{Z}$ youngsters under normal circumstances, but during this period of isolation even this agegroup reported a significant increase in time spent on media consumption. This is closely related to the fact that during the period under review all major everyday activities moved to the media space, including learning, working, keeping in touch with friends, acquaintances, relatives, collecting information, entertainment, and leisure activates in general. According to user reports, the rapidly developing monotony in quarantine was also resolved by the media since variety as such was represented by the switching between different media devices and media platforms related to different activities. Thus, for example, while the typical tool for learning and working was the laptop and the Internet, television and traditional linear broadcasting, such as watching popular television series, often appears as a means of entertainment and recreation. Media-related user attitudes towards daily routines varied widely across the sample. Young people who identified themselves as introverted (with specific comments referring to this in the texts) initially experienced the period from March to early June as "heaven". They argued that the confinement gave them the opportunity to do jobs and tasks that they had not had time for before and that for them the lack of personal encounters and company was not a particular problem. In contrast, youngsters who reportedly have extroverted personality traits experienced serious discomfort as early as a few weeks after the quarantine had started, because in their case virtual encounters and programmes could not trigger the experiences provided by personal meetings. In conclusion, media use was an essential factor in the quarantine period; it was as for everyone almost the only permanent connection with the outside world. 


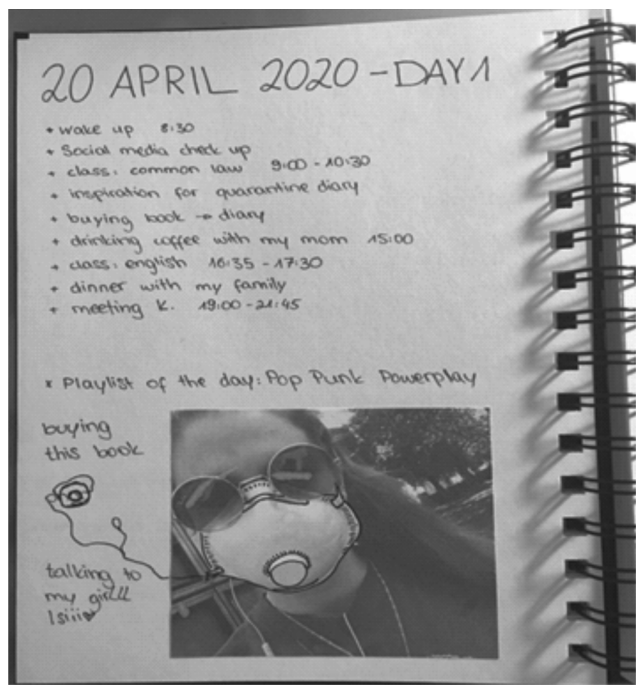

Picture 1. List of daily tasks in the quarantine diary of a student from Stuttgart

The above-mentioned phenomenon is well illustrated by the following diary quote, which simultaneously reflects on the tension caused by the isolation, lack of company, and media use as a typical escape from all of these:

I live my social life digitally. Because I consider the quarantine important, I have very rarely left home since the declaration of the state of emergency. Therefore, I have perceived the lack of connections much more intensely in recent weeks than any other effects of the quarantine. So, the question is how I defend myself against the frustrations caused by the corona virus. Since our apartment is new and we have moved in recently, it is not yet very equipped, and it is inevitable that a few things disappear during the move. The implication of this for me was that in the absence of material and space, foreign faces and communication, I had a hard time finding a leisure activity with which I could occupy myself for a longer and meaningful time. Due to the lack of social connections, I spent these times with video games and online communication. (Ádám, male, 23)

\section{General Patterns of Media Consumption}

The second issue of the study addressed the question of how the pattern of media use of young people developed during the quarantine period. In this context, the most typical experience was the feeling of media overuse, which means that the informants also thought - based on their own impressions - that they had spent 
too much time in the company of the media during the sampling period. This was partly explained by the fact that hardly any other opportunities for entertainment and recreation were available besides the media, and, on the other hand, a state of "dependence on the media" developed after a while. By this they meant that the media "sucked them in", meaning that one content pulled the other, and finally they spent long hours consuming content while completely forgetting about the passage of time. The example of Netflix is repeatedly mentioned in the reports in connection with the phenomenon, which platform proved to be an addictive factor for many during the quarantine period. For example, one of the students wrote in his diary that the streaming service provider's amazing content offerings, mainly series, glued him to the screen, which became disturbing after some time and led to dysfunctional behaviour such as obesity due to lack of physical movement, mood swings due to confinement, failure to perform tasks and duties (Picture 2). In connection with this experience, the feeling of stimulus oversupply became rather typical - by this we mean that the time spent in the company of the media resulted in an increase in stimuli. This phenomenon was only worsened by the fact that in the flood of content provided by a wide range of platforms all actors fought for the attention of users and service providers tried to offer as interesting and up-to-date content as possible by overbidding one another. On the users' side, this activity was manifested in two ways. On the one hand, many people reported fatigue, exhaustion - as many put it: the hours of inactivity spent in the company of the media became just as exhausting in a few days' time as normal everyday life at work or university. On the other hand, many of the students experienced time pressure, which means that there was a tension between consumers' finite amount of leisure/media time and the influx of seemingly endless, exciting content. Many people tried to bridge these problems with the practice of multitasking, that is, to use several tools or interfaces at the same time in order to consume more content more efficiently. This typically meant using traditional television and online platforms at the same time. The general appearance of background media use served the same purpose, in which case media use appeared in parallel with activities related to daily routine (such as cleaning, cooking, or exercising). As a result of the practices mentioned above, there has been a need for a "digital detox", that is, a determination for users to consciously reduce the amount of time they spend using the media. In this process, we can trace the emergence of self-regulation, which was mainly activated in cases where the user clearly recognized that excessive media use had already unfavourably affected his or her well-being, mood, or relationship with friends, family, and acquaintances. In conclusion, the report suggests that the media played a dual role during the quarantine: not only did it liberate users and meant an escape from the cruel reality, but it also shut them down many times, imprisoning them in a virtual world. 


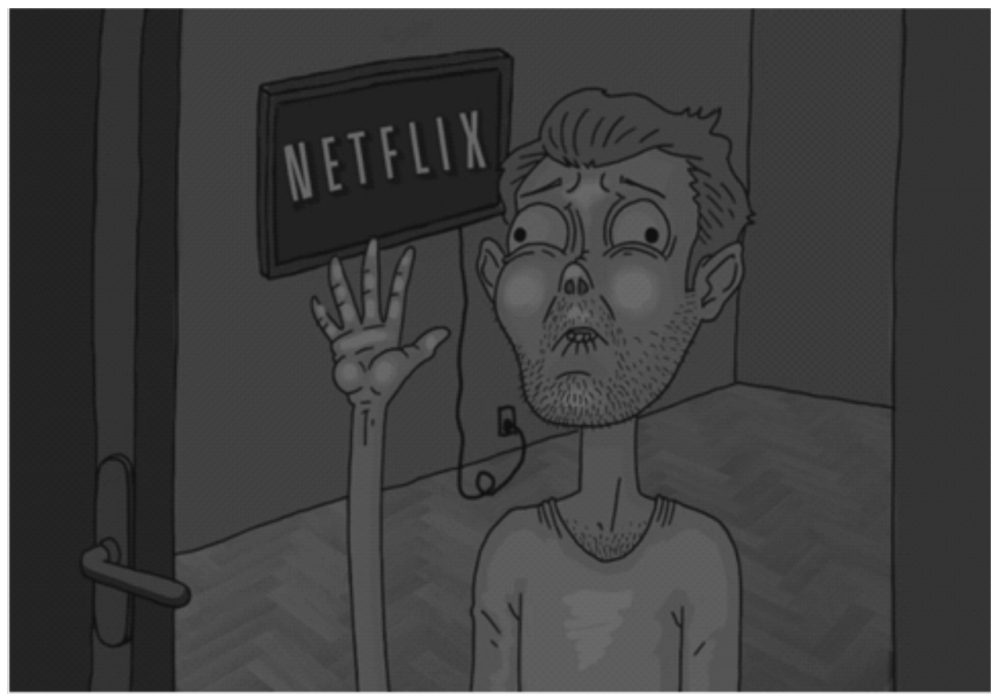

Picture 2. Visual reflection on the addictive effects of Netflix by Ádám Mohai, student of PTE, Faculty of Arts

\section{News Consumption}

Reflecting on the fact that large-sample research results, without exception, reported a much higher rate of news consumption during the quarantine, this issue also received special attention in our own research. Indeed, in international research material published since April 2020, we often find that consumer interest in news has increased significantly due to the fears and uncertainties created by the epidemic. During this period, people who are not regular news consumers would normally also click on news sites more often. Recognizing the phenomenon, service providers began to compete and started to publish and update news items with an incredible speed and with more and more attention-grabbing and shocking headlines. After a few weeks, the process was given the name "infodemic", or information pandemic, by experts. ${ }^{9}$ The term also reflects on the negative effects of the practice, namely that consumers had become increasingly insecure because of the growing news competition about the epidemic as more and more fake news and horror news emerged in the information tsunami - often in mainstream news sites as well. Changes in the media, the soaring influx of news, also had an impact on consumer practices. This appeared in a form of an urgent pressure to consume news items, which can be clearly seen in the students' reports. This was mainly due to users trying to keep up with the latest news every minute of the day; so, while recording diaries, more and more people realized that they had spent long hours constantly updating news pages while hunting for the latest broadcasts.

9 https://www.nytimes.com/2020/02/06/health/coronavirus-misinformation-social-media.html. 
Even those who did not consciously seek out the news about the epidemic could not escape them, and this phenomenon can be highlighted by the difference between active and passive consumption of news. While we consider active news consumers to be users who themselves search for information about the epidemic, passive news consumers are those who meet the news items indirectly, mainly via their friends and relatives through online shares. In the latter case, a feeling of serious discomfort developed in some people who felt unable to exclude the threat of the epidemic from their lives, generating constant insecurity and quite often frustration and depressive attitudes as well. As a result of such news, many also experienced feelings of confusion and despair and struggled with the ambivalent feeling that the media was both a means of escape and relaxation, while the same tool was a source of news from the terrifying outside world. This inconsistency is embodied in the paradox of reassuring media versus threatening media, which had led many to withdraw from the media and voluntarily undertake digital detoxification. The processes mentioned here are well illustrated by the amount of contradictory information provided by the Hungarian media in a short period of time about the possible advantages and disadvantages of wearing a mask - in connection with this, even the extreme situation arose that official news sources gave completely contradictory advice within a single day. The uncertainties and tensions associated with this are also reflected in the diaries such as in the pictures below (Picture 3) and the related entries.

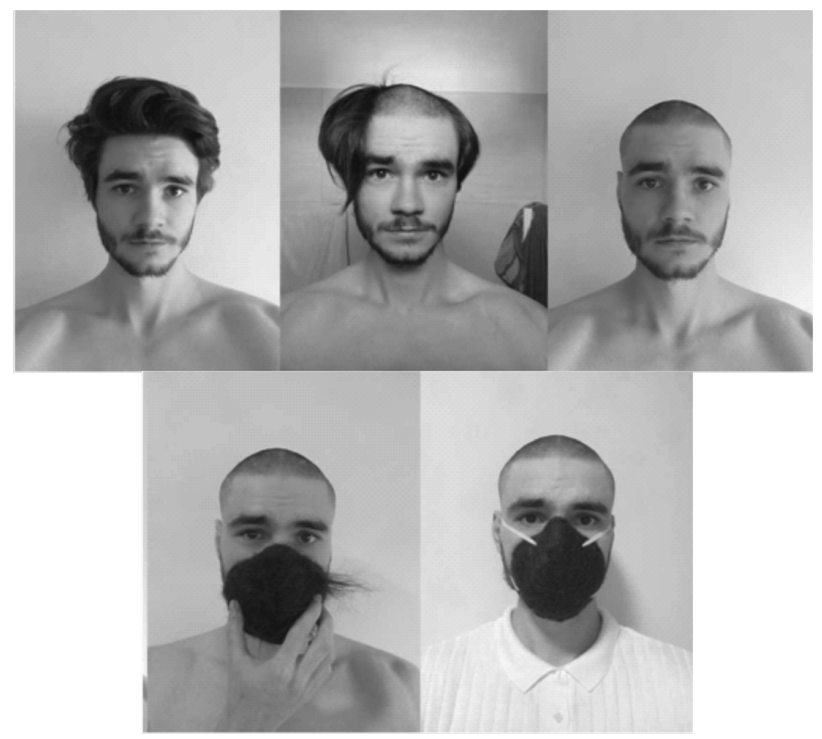

Picture 3. Reflection of Marcell Hamza, a student of the Faculty of Arts at the University of Pécs, on the tensions caused by the contradictions related to wearing a mask 
I don't need my "crown" anymore (mask made of hair). My hair's "job" is to protect my scalp from the sunshine, and it has aesthetic purposes too. However, I can't take full advantage of it due to the quarantine, so I don't need it anymore. One of the most noticeable changes in the current situation is that people cannot go to the hairdresser. It may seem like a tiny problem, but it spectacularly illustrates with the help of the body what usual routines we have to give up in this situation. Reflecting on this, with regard to my lack of material, I decided to use my almost disturbing mass of hair for my work, the hair that grew during my quarantine. This act symbolizes the present conditions and choosing health over the protection of my scalp or beauty. On the other hand, I'm thinking about starting to make masks in a personalized way. I consider it as a material and moral symbol in the name of a commitment to quarantine. (Maybe, if there is a demand for, I would prepare the masks using the customer's hair. Although I don't think there would be many applicants for it.) (Marcell, male, 22)

\section{Online Learning and Work}

During quarantine, Generation $\mathrm{Z}$ youth were able to take part in education via online applications, and, because many of the young people in the sample are already working in addition to their studies, the media space has also become a space for learning and working as well. The transition was reportedly not a particular challenge for young people, and new routines for online learning and working emerged within about a week following the declaration of the quarantine. Some students saw the transition as a positive change. For example, with the elimination of commuting between home and university or work (being mentioned by almost everyone), they were more effective, and they could experience the benefits of a more efficient scheduling. At the same time, in addition to the positive changes, some inconveniences were also expressed by the informants. In addition to connection problems and technical difficulties, one of the most common problems mentioned was the so-called "always on" mode, which means that students were supposed to be in a constant standby status all day long. The always on mode suggests that due to constant availability and online presence, after a while, time spent studying and working is completely blurred with leisure time, and the spheres of the university and the workspace are persistently pushed into the private sphere, often causing tension or awkward life situations. One of the typical manifestations of the always on mode can be read in the following entry, which comes from a student who has also taken up a job in addition to her studies: 
I barely woke up today. I was already terrified when I opened my email account: I got about 12 emails from my boss. Yes, I know, I know this is one of my worst habits, so people shouldn't open email accounts first because our brains are starting to spin on things to do right away. In the morning, I always tell myself that it can't be my first thing to read emails right after I open my eyes. Though I always set a reminder, I do this for three or four days, and then everything goes on as before. But it's very boring now. It would be nice to meet my teammates and co-workers. But let's go back to the emails. There are a lot of them. (Mercédesz, female, 23)

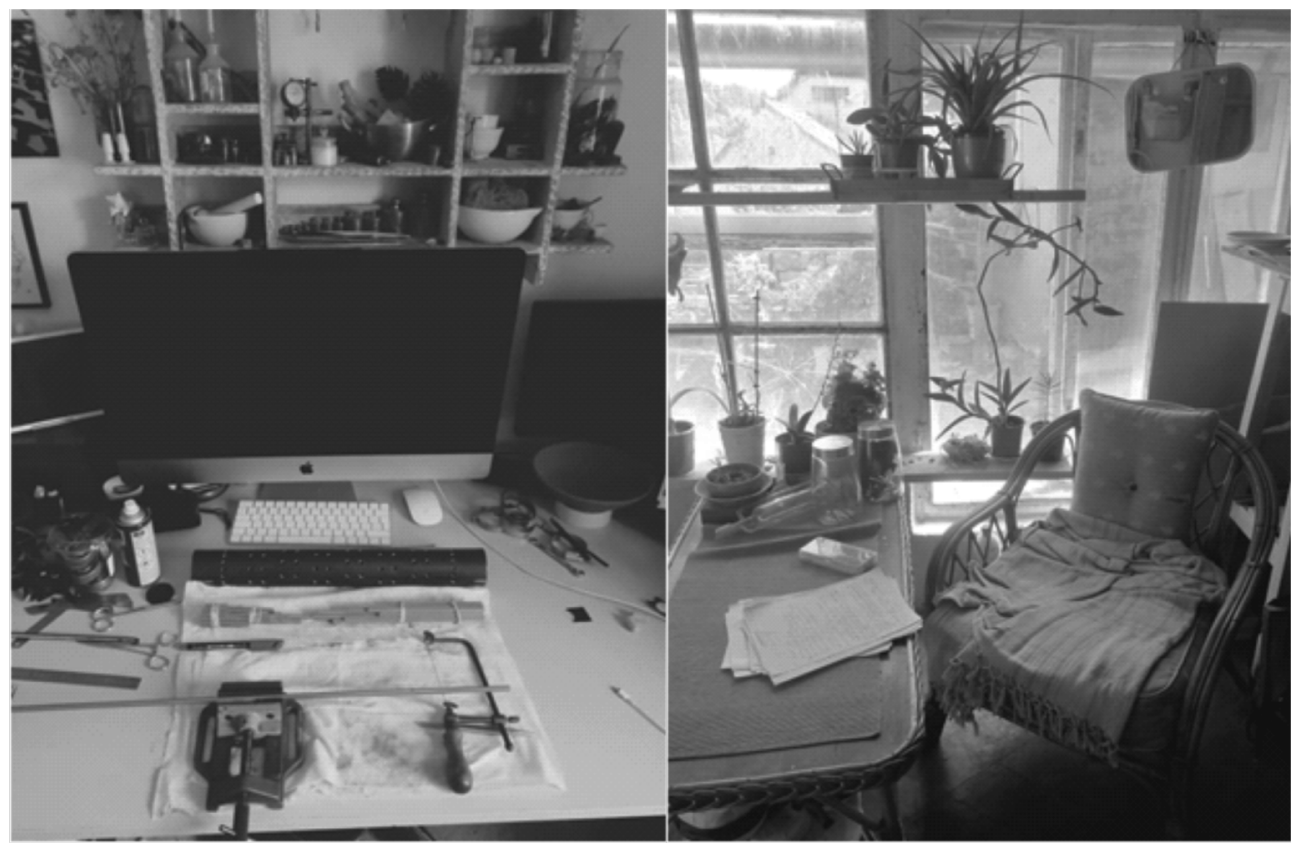

Picture 4. Typical spaces for learning and work - photographic documentation related to quarantine diaries from Hungarian and German students

Among the negative experiences, the respondents also mentioned the problem that in accordance with the constantly changing university and workplace requirements more and more new applications had to be downloaded and used by them every single day. Domestication, that is, the incorporation of new applications into everyday practice, did not go smoothly either, and ambivalent feelings often arose in this regard as well. While almost everyone agreed that they had never been able to learn and use so many useful new applications in such a short period of time, it was clear that all of this consumed a lot of time and energy, especially for those who were less open to innovations in the digital world. In this context, it 
is also worth mentioning that the reports show that not only new technical skills emerged in the process, but new cultural practices and rules developed along with the new routines. A good example of this is the emergence of a set of cultural rules for online meetings and discussions over video calls. These include the practice that, after a time, participants grew accustomed to turning off their microphones whenever they were not speaking in order to eliminate disturbing external noise, and in the same way new rules appeared regarding what to wear or what kind of background to show during video calls. In conclusion, results suggest that although technology helped and solved many things during the quarantine, at the current state of technology, online learning or work cannot yet fully replace personal presence and meetings in real space and real time.

\section{Effects}

In the extreme situation created by the epidemic, the questions of how the media affects the audience and how these effects are perceived and interpreted by the recipients become especially interesting. Examining the effects of media is always problematic as we know that different media contents have different effects on different people (Bajomi, 2017). Within the framework of the present study, our aim was not to formulate general, representative statements about the effects of quarantine media. In contrast, our aim was to identify on the basis of individual reflections the characteristic attitudes that were presumably present in the case of other users too while taking into account that larger differences in effects depending on the social-cultural environment and personality are also possible. Comparing the results, it can be stated that the majority of respondents were able to report a predominance of positive effects. Most of these are based on the insight into functional benefits associated with the media, i.e. users were able to realistically assess how many areas the media had helped them to perform their tasks even in isolation. The media helped to survive the epidemic-generated extreme situations, engage in education and work, and provide opportunities to connect with friends, classmates, and distant relatives even when online learning, work, and virtual meetings could not fully replace personal presence. Among the positive effects, it is worth highlighting the recreational function of the media, which in the case of Generation $\mathrm{Z}$ respondents can be seen mainly in watching series and listening to online music streams - this result clearly coincides with the research assumptions of the Global Web Index research. At the same time, it is important to highlight that there are several negative effects mentioned in the responses, including lack of motivation, feelings of wasted time, poor time management in general, tension, and frustration. An interesting result is that one of the most frequently mentioned symptoms of these was insomnia, which could manifest itself in two ways (Picture 5). On the one hand, this may have been 
due to excessive content consumption, when the time of media consumption extended to the period that is normally spent by sleeping, for example in the case of new serial addicts. On the other hand, many students reported that the news seen and heard during the day generated a degree of fear and tension in them that resulted in the upset of the normal sleep cycle. One student put it this way:

This insomnia is driving me crazy! I played online for 2 hours at dawn because I couldn't fall asleep. The real problem is that I can barely get up in the morning. I always say that I should have been born on the other side of the Earth because it's morning there when I'm awake and evening when I can sleep. I'm a night owl - somehow my brain works better at night -, but it's no longer healthy that I want to sleep, but my body won't let me. I am always very tired during the day. (Andrea, female, 22)
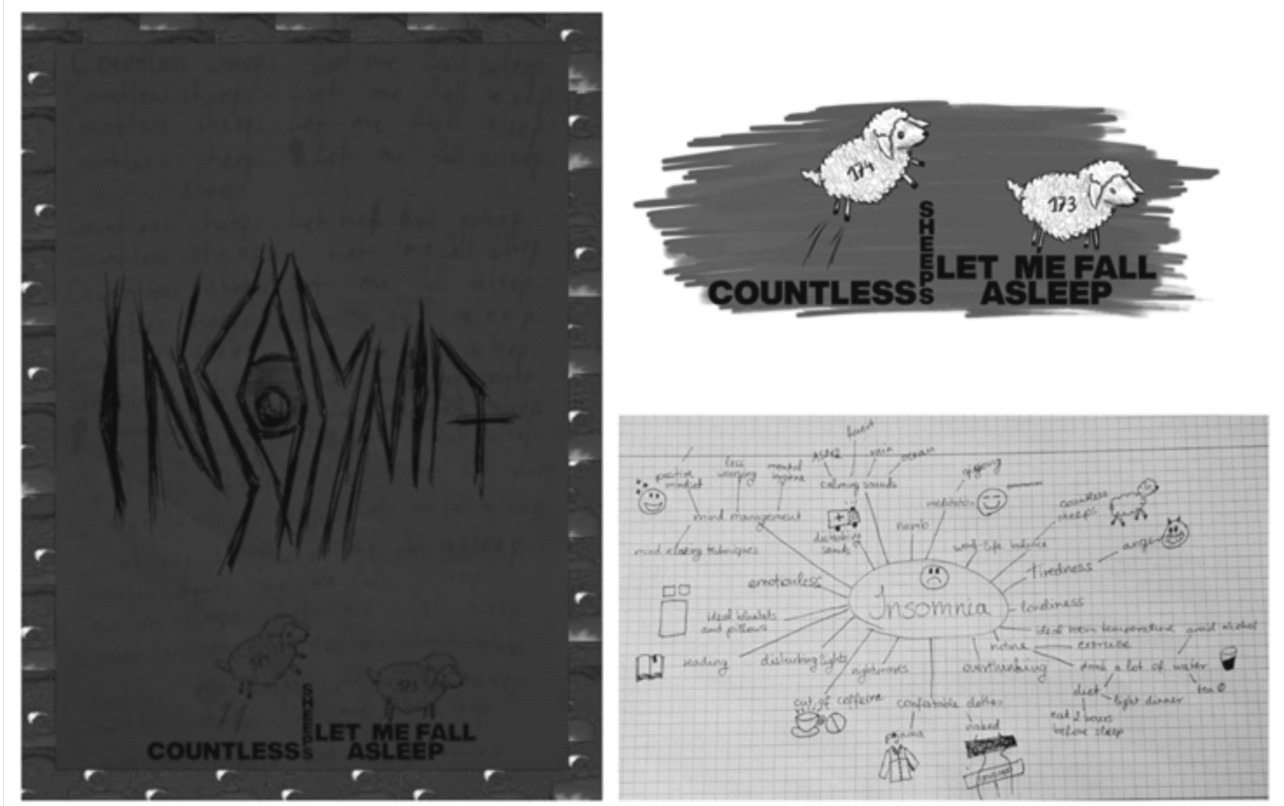

Picture 5. Reflections of Hungarian and German students on the phenomenon of media-induced insomnia 


\section{Conclusions}

As a summary of the joint research project of the PTE and HFK+G, it can be stated that the results of the qualitative study coincide with the experiences of the large-sample international surveys, and they can help us to refine and fine-tune them. In this regard, based on the results, one of our most important findings may be that during the quarantine even members of Generation Z, who are considered "digital natives", were fed up with the extreme use of media, that is, every important aspect of their lives moved online for months. The time they spent on using media, sometimes more than 10-12 hours a day, became unpleasant after a few weeks, even if users could easily see that the media had provided significant help in solving the challenges and problems caused by the quarantine. Whether we approach the issue from the point of view of daily routine and media, the general pattern of media consumption, news consumption, online learning and work, or media effects, it is clear that digital media was a huge help in surviving the COVID-19 epidemic, and the extent to which students were able to successfully adapt to the changing circumstances may depend to a large extent on whether the respondents were conscious users of the media or "media citizens" (Mosco, 2003). If they were conscious users, they survived this stressful period with fewer "injuries".

\section{References}

Bajomi-Lázár, P. (2017). Manipulál-e a média? [Does the Media Manipulate?]. Médiakutató 2017(winter): 61-79.

Guld, Á. (2014). Mozgásban - A Z-generáció médiahasználati szokásairól [On the Move - The Media Usage of Generation Z]. Média, Kábel, Múhold 18(5): 24-26. Guld, Á.-Maksa, Gy. (2013). Fiatalok kommunikációjának és médiahasználatának vizsgálata. Kutatási jelentés [Examining the Communication and Media Use of the Youth. Research Report]. TÁMOP-4.2.3-12/1/KONV-2012-0016 Tudománykommunikáció a Z generációnak kutatás keretein belül. Pécs: University of Pécs. http://www.zgeneracio.hu/tanulmanyok.

Hepp, A.-Berg, M.-Roitsch, C. (2011). Mono-Thematic and Multi-Tthematic Horizons of Mediatized Communitization: Patterns of Communicative Networking and Mediated Belonging. Studies in Communication/Media 2011/2: 1-34.

Horning, S. (2009). Doing Media Research. London: Sage.

Howe, N.-Strauss, W. (1991). Millennials Rising: The Next Great Generation.

New York: Vintage Books.

Hugh, M. (1997). Generations. Sidney: Pan. 
Macmillan, P. M. (2001). Digital Natives, Digital Immigrants I-II. On the Horizon 9(5). NCB University Press. https://www.marcprensky.com/writing/ Prensky\% 20-\% 20Digital\%20Natives, \% 20Digital\% 20Immigrants \% 20-\% 20 Part2.pdf.

Mosco, V. (2003). Citizenship and the Technopoles. In: Lewis, J.-Miller, T. (eds.), Critical Cultural Policy Studies Reader. Malden, MA, USA - Oxford, UK: Blackwell Publishing.

Sheble, L.-Wildemuth, B. (2009). Research Diaries. In: Wildemuth, B. (ed.), Applications of Social Research Methods to Questions in Information and Library Science. Westport, CT: Libraries Unlimited, 211-221.

Stokes, J. (2008). A média- és kultúrakutatás gyakorlata [How to Do Media and Cultural Studies]. Budapest-Pécs: Gondolat.

Törőcsik, M. (2015). A Z generáció magatartása és kommunikációja [Communication and Behaviour of Generation Z]. Pécs: University of Pécs.

\section{Cite as:}

Guld, Á. (2020). Project (I)solation - Everyday Life and Media Use During the COVID-19 Pandemic. Acta Universitatis Sapientiae, Communicatio 7: 25-41. DOI: 10.2478/auscom-2020-0003. 